\title{
VARIABILITY OF QUANTITATIVE AND QUALITATIVE TRAITS OF COLOURED WINTER WHEAT
}

\author{
ALŽBETA ŽOFAJOVÁ ${ }^{1 *}$, MICHAELA HAVRLENTOVÁ ${ }^{1,2}$, MIROSLAV ONDREJOVIČ ${ }^{2}$, \\ MAROŠ JURAŠKA ${ }^{1}$, BARBORA MICHALÍKOVÁ ${ }^{2}$, L'UBOMÍRA DEÁKOVÁ ${ }^{1}$
}

\author{
${ }^{1}$ National Agricultural and Food Center - Research Institute of Plant Production Piešt'any, \\ Slovak Republic \\ ${ }^{2}$ University of Ss. Cyril and Methodius, Trnava, Slovak Republic
}

ŽOFAJOVÁ, A. - HAVRLENTOVÁ, M. - ONDREJOVIČ, M. - JURAŠKA, M. - MiCHALÍKOVÁ, B. - DEÁKOVÁ, L.: Variability of quantitative and qualitative traits of coloured winter wheat. Agriculture (Pol'nohospodárstvo), vol. 63,2017 , no. 3, p. 102-111.

\begin{abstract}
The aim of research was to analyse winter wheat of different grain colour and to compare newly bred coloured genotypes from our breeding in grain yield and technological and nutritional quality. The set of seven purple, five blue and four yellow wheats of different origin, including seven newly bred genotypes from Vígl'aš-Pstruša, was evaluated in the field experiments established by randomised complete block design in two replications in Piešt'any, in the vegetations 2012/13 and 2013/14. In seven wheat varieties differing in grain colours (selected after two of each colour plus control red variety Ilona) anthocyanin composition was evaluated by HPLC analysis. Significant differences were between growing years and among colour groups in most analysed traits. Blue grain newly bred K 3575 699/3 showed the highest anthocyanin content (by $33.5 \%$ higher compared to blue grain registered variety Scorpion). However, blue grain genotypes showed negative agronomic traits combined with low number and grain weight per spike and high plant height. In new purple variety PS Karkulka, declared grain yield and its quality were confirmed and the highest mineral content ( $\mathrm{Fe}, \mathrm{Zn}, \mathrm{Cu}, \mathrm{Mn}$ ) was found in selected set. Purple grain newly bred PS 5711 had lower anthocyanin content (by 17.7\%), but in quality it was comparable to PS Karkulka. Varieties with yellow endosperm showed the highest number and weight of grains per spike, however it was significantly lower to Ilona. The breeding goal of coloured winter wheat is still to improve the grain yield as well as additional agronomics traits.
\end{abstract}

Key words: winter wheat, grain colour, grain yield, quality, HPLC, anthocyanin

In wheat breeding, in addition to obligate traits (grain yield, quality, and tolerance to biotic and abiotic stresses), new directions are aimed on increasing health promoting substances. The anthocyanins represent a new goal for wheat genetic improvement. In colour wheat anthocyanins are located either in a purple pericarp, or in blue aleurone and carotenoids in the endosperm. Renewed interest for wheat breeding with a high anthocyanins content is linked to various health benefits associated with anthocyanins from their natural sources. Studies have shown that anthocyanins have antioxidant (Reque et al. 2014, Ficco et al. 2014), anti-cancer (Fernandes et al. 2014), anti-obesity (Esposito et al. 2015, Johnson et al. 2016), and anti-inflammation effects (Esposito et al. 2014). However, it is unknown whether these health benefits are solely due to anthocyanins or the synergistic effect of diverse phytochemicals (Li et al. 2017).

Common wheat varieties, which are characterized by purple, blue or yellow grains are actually

Ing. Alžbeta Žofajová, PhD. (*Corresponding author), RNDr. Michaela Havrlentová, PhD., Mgr. Maroš Juraška, Mgr. Lubomíra Deáková, National Agricultural and Food Center, Research Institute of Plant Production Piešt’any, Bratislavská cesta 122, SK-92168 Piešt’any, Slovak Republic

Doc. RNDr. Miroslav Ondrejovič, PhD., Mgr. Barbora Michalíková, University of Ss. Cyril and Methodius, Faculty of Natural Sciences, Department of Biotechnology, Námestie J. Herdu 2, SK-91701 Trnava, Slovak Republic 
produced in small amounts, but growing interest has recently been shown in the genetic development of novel pigmented varieties (Jaafar et al. 2013, Martinek et al. 2013b). The winter wheat variety Scorpion with blue grain colour was registered in 2011 in Austria and in 2012 it was also registered in European list of cultivars (Martinek et al. 2013b). In 2013 in Slovakia, the first local winter wheat variety PS Karkulka with purple grain was registered (Hanková et al. 2014). Varieties Bona Dea and Bona Vita with yellow endosperm were bred and registered in Slovakia in 2006 and 2011, respectively. Varga et al. (2013) analysed the anthocyanin content of blue and purple wheat cultivars and their hybrids cultivated under Hungarian growing conditions. Jaafar et al. (2013) evaluated progeny from crosses between red, purple and blue grained wheat varieties selected over several cycles. The results showed that increasing anthocyanin content is possible by the combination of different genetic backgrounds for purple pericarp and blue aleurone. In fact, these unconventional varieties might be important sources of biologically active phytochemicals and as a result, they could be valuable as a raw materials for the production of functional foods (Ficco et al. 2016). Higher anthocyanin content of blue and purple wheat can be exploited to the anthocyanin content of bakery products if whole-meal flour or bran are used $(\mathrm{Li}$ et al. 2015). The content of yellow pigment is studied mainly in $T$. durum for producing superior pasta products (Lachman et al. 2017).
The aim of research was to evaluate the variability of quantitative and qualitative traits of different grain coloured winter wheat and to compare newly bred coloured genotypes originated from local breeding programmes.

\section{MATERIAL AND METHODS}

Evaluated set of winter wheats consisted of 17 varieties and genotypes (next variety) of different grain colour - seven purple samples (K 3517, K 3513, 994/3, PS Karkulka, PS 5711 from Research and Breeding Station at Vígl'aš-Pstruša, Indigo (GB), Zernofialovetaja (unknown origin)), five blue (K 3575 699/3, 930/1 from Research and Breeding Station Vígl'aš-Pstruša, Barevná 9, Barevná 25 (CZ), Scorpion (AT)), four yellow (Bona Dea, Bona Vita (SK), Luteus, Citronova (synonym Citrus) (DE)). As a control, local variety Ilona with standard red grain colour was used. Field experiments were established by randomized complete block design in two replications at the Research Institute in Piešt'any (west part of Slovakia) in the vegetative years 2012/13 and 2013/14. Experimental unit consisted of a $1 \mathrm{~m}^{2}$ plot. Locality is at an altitude of $163 \mathrm{~m}$ with a continental character of climate, long-time average annual precipitation is $608 \mathrm{~mm}$ and temperature $9.2^{\circ} \mathrm{C}$. Soil type was Luvi-Haplic Chernozem; the locality belongs to a maize production type. In the Table 1 month precipitations and average temperatures are presented.

$$
\mathrm{T} \text { a } \quad \mathrm{b} \quad 1 \text { e } 1
$$

Precipitations and average temperature over two growing seasons (2012/13, 2013/14) at Piešt'any, Slovakia

\begin{tabular}{|l|c|c|c|c|c|c|c|c|c|c|c|}
\hline Month & 10 & 11 & 12 & 1 & 2 & 3 & 4 & 5 & 6 & 7 & Sum, mean \\
\hline $\begin{array}{l}\text { Normal } \\
{[\mathrm{mm}]}\end{array}$ & 40 & 52 & 46 & 32 & 33 & 28 & 40 & 66 & 72 & 59 & 468 \\
Normal $^{*}$ temperature $\left[{ }^{\circ} \mathrm{C}\right]$ & 9.7 & 4.2 & -0.1 & -2.0 & 0.4 & 4.5 & 9.6 & 14.5 & 17.4 & 18.9 & 7.9 \\
\hline \multicolumn{8}{|c|}{$2012 / 13$} \\
\hline $\begin{array}{l}\text { Precipitations }[\mathrm{mm}] \\
\text { Temperature }\left[{ }^{\circ} \mathrm{C}\right]\end{array}$ & 63.4 & 15.8 & 26.2 & 37.4 & 68.8 & 70.6 & 9.8 & 40.8 & 102.4 & 3.0 & 438.2 \\
\hline & 10.3 & 7.7 & -1.1 & -1.2 & 0.9 & 2.6 & 11.5 & 15.3 & 18.7 & 22.4 & 8.71 \\
\hline Precipitations $[\mathrm{mm}]$ & 25.0 & 46.8 & 3.6 & 21.0 & 25.2 & 11.4 & 54.2 & 75.6 & 29.6 & 95.0 & 387.4 \\
Temperature $\left[{ }^{\circ} \mathrm{C}\right]$ & 12.1 & 6.7 & 2.7 & 3.0 & 3.2 & 8.5 & 11.8 & 15.2 & 19.2 & 21.7 & 10.4 \\
\hline
\end{tabular}

*(1961-1990) 
During the growing seasons standard cultivation practices were used. Within vegetations obligate traits were observed. In maturity, an average sample of 300 productive ears was collected from each plot and the number and weight of grains per ear and 1,000 grain weight (TGW) were determined. Protein, starch, gluten content and Zeleny test were assayed by the DA 7200 NIR analyser.

Extraction of anthocyanins from wheat grain bran and determination of total anthocyanins using the $\mathrm{pH}$ differential method were described in Žofajová et al. (2012).

Composition of anthocyanins, total ash and microelements ( $\mathrm{Fe}, \mathrm{Zn}, \mathrm{Cu}, \mathrm{Mn}$ ) were determined in wheat varieties grown in 2013/14 (PS Karkulka, PS 5711, K 3575 699/3, Scorpion, Bona Vita, Luteus) selected after two of each colour group plus control (red) variety Ilona.

\section{Composition of anthocyanins}

The anthocyanins were extracted according to the method described by Abdel-Aal and Hucl (2003), with a modification according to Ficco et al. (2014). Homogenized cereal grain material $(500 \mathrm{mg})$ was extracted twice by $8 \mathrm{ml}$ of methanol acidified with $1.0 \mathrm{M} \mathrm{HCl}(85: 15, \mathrm{v} / \mathrm{v})$ at laboratory temperature for 30 minutes. Crude extracts were centrifuged at 9,000 RPM for 15 minutes. Separated supernatants were filtered through $0.45 \mu \mathrm{m}$ cellulose syringe filters before HPLC analysis.

The Agilent 1200 Series HPLC System (Agilent Technologies, Santa Clara, CA, USA) used for analysis consists of a binary pump, the DAD SL detector, degasser, and column temperature controller. System control and data analysis were processed using the Agilent ChemStation software Rev. B.04.03 (Agilent Technologies, Santa Clara, CA, USA). The chromatographic separation was performed in Eclipse XD8-C18 column $(3.5 \mu \mathrm{m}, 3.0 \times 100 \mathrm{~mm})$ using water solution of formic acid (A; 4.5\%, v/v) and methanol (B) as mobile phase at flow rate of 0.4 $\mathrm{ml} / \mathrm{min}$. The gradient program was set as follows: 0-30 min, 10-25\% B; 30-40 min, 25-45\% B; 40-42 min, 45-90\% B; 42-45 min, 90\% B. The chromatogram was monitored at a wavelength of $520 \mathrm{~nm}$ throughout the experiment. The column temperature was maintained at $30^{\circ} \mathrm{C}$ and the injection volume of each sample and standard solution was $10 \mu$ l. The
HPLC mobile phase was prepared fresh daily, filtered through $0.45 \mu \mathrm{m}$ membrane filter and then degassed before injection into the column.

\section{Determination of total ash}

For determination of total ash in wheat samples ashing furnace Carbolite AAF 1100 was used. The whole test of total ash was performed via STN ISO 2171. Each sample was prepared in duplicate.

\section{Determination of microelements}

All measurements were performed using an Agilent 4200 MP-AES with nitrogen plasma gas supplied via an Agilent 4107 Nitrogen Generator. The instrument operated in a fast sequential mode and featured a Peltier-cooled CCd detector.

Microwave digestion was used to prepare all wheat samples for total metal analysis of $\mathrm{Cu}, \mathrm{Zn}$, $\mathrm{Mn}$ and Fe by MP-AES. $7 \mathrm{~mL}$ of $65 \% \mathrm{HNO}_{3}$ and $1 \mathrm{~mL}$ of $30 \% \mathrm{H}_{2} \mathrm{O}_{2}$ was added to $0.5 \mathrm{~g}$ of the sample. A preloaded method for the Milestone ETHOS 1 microwave system was used to digest the sample. Once cooled, the solution was diluted to $50 \mathrm{~mL}$ using ultrapure water. Each sample was prepared in triplicate and the quality of the MP-AES results was evaluated by comparing them with the values for reference material, strawberry leaf, Metranal 3.

The data were analysed by analysis of variance using Statgrafics Centurion X64.

\section{RESULTS AND DISCUSSION}

\section{Effect of vegetative year (Table 2)}

Significant differences were observed between vegetative years in all traits except grain number per ear. In seven evaluated traits (from eleven), higher average values were found in the vegetative year 2012/13 compared to subsequent one. The vegetation 2012/13 was in average by nine days exceed (not shown) and heading of varieties was by 10.9 days later, what was caused by later beginning of vegetation (average temperature in March 2013 was only $2.6^{\circ} \mathrm{C}$ ) (Table 1 ). In analysed traits such as protein complex and Zeleny test higher results were observed in vegetation 2012/13 (from 13.6\% for protein content to $18.9 \%$ for Zeleny test). The higher amount of precipitation (by $50.8 \mathrm{~mm}$ ) and lower average temperature (by $1.7^{\circ} \mathrm{C}$ ) during the growing 
season 2012/13 (Table 1) also positively influenced anthocyanin and ash content (increasing by $17.8 \%$ and $8.1 \%$, respectively). Anthocyanin content is affected by environmental factors, e.g. weather conditions and soil type and quality, what was also expressed in significant interaction year $\times$ variety (not shown). Similarly, in spring wheat Abdel-Aal et al. (2016) found that genotype, year and location

$\mathrm{T}$ a b 1 e 2

Mean values of traits of 17 coloured winter wheat evaluated over two growing seasons $(2012 / 13,2013 / 14)$ at Piešt'any, Slovakia

\begin{tabular}{|c|c|c|c|c|}
\hline \multirow{2}{*}{ Trait } & \multicolumn{2}{|c|}{ Growing season } & \multirow{2}{*}{ Mean } & \multirow{2}{*}{$L S D_{0.05}$} \\
\hline & $2012 / 13$ & $2013 / 2014$ & & \\
\hline HEA & $25.8^{\mathrm{b}}$ & $14.9^{\mathrm{a}}$ & 20.3 & 0.86 \\
\hline $\mathrm{PH}$ & $101.7^{\mathrm{a}}$ & $118.0^{\mathrm{b}}$ & 109.9 & 3.07 \\
\hline TGW & $42.4^{\mathrm{a}}$ & $47.6^{\mathrm{b}}$ & 45.0 & 1.74 \\
\hline GN & 43.5 & 42.4 & 43.0 & 2.95 \\
\hline GW & $1.85^{\mathrm{a}}$ & $2.03^{b}$ & 1.94 & 0.45 \\
\hline $\mathrm{PC}$ & $13.4^{\mathrm{b}}$ & $11.8^{\mathrm{a}}$ & 12.6 & 0.38 \\
\hline $\mathrm{SC}$ & $61.3^{\mathrm{a}}$ & $62.3^{\mathrm{b}}$ & 61.8 & 0.34 \\
\hline GC & $28.5^{\mathrm{b}}$ & $24.9^{\mathrm{a}}$ & 26.7 & 0.83 \\
\hline $\mathrm{ZT}$ & $45.8^{\mathrm{b}}$ & $38.5^{\mathrm{a}}$ & 42.2 & 0.98 \\
\hline TAC & $44.3^{\mathrm{b}}$ & $37.6^{\mathrm{a}}$ & 41.0 & 3.10 \\
\hline $\mathrm{ASH}$ & $1.72^{\mathrm{b}}$ & $1.59^{\mathrm{a}}$ & 1.65 & 0.06 \\
\hline
\end{tabular}

HEA - heading [number of days from May, 1]; PH - plant height [cm]; TGW - thousand grain weight [g]; GN - grain number per ear [piece]; GW - grain weight per ear [g]; PC - protein content [\%]; SC - starch content [\%]; GC - gluten content [\%]; ZT - Zeleny test [ml]; TAC - total anthocyanin content $[\mathrm{mg} / \mathrm{kg}] ; \mathrm{ASH}-$ ash content $[\%]$

$L S D_{0.05}$ - least significant difference at the level $\alpha=0.05$

Different letters indicate significant differences at $P<0.05$

T

Descriptive statistics of traits of coloured winter wheat groups over two growing seasons (2012/13, 2013/14) at Piešt'any, Slovakia

\begin{tabular}{|c|c|c|c|c|c|c|c|c|}
\hline \multirow{2}{*}{ Trait } & \multicolumn{2}{|c|}{ purple $(n=7)$} & \multicolumn{2}{|c|}{ blue $(n=5)$} & \multicolumn{2}{|c|}{ yellow $(n=4)$} & \multirow{2}{*}{$\frac{\text { control }}{\text { mean }}$} & \multirow{2}{*}{$L S D_{0.0}$} \\
\hline & mean & range & mean & range & mean & range & & \\
\hline HEA & 19.8 & $5.0-26.0$ & 23.7 & $5.0-37.0$ & 18.8 & $3.0-35.0$ & 9.5 & 4.91 \\
\hline $\mathrm{PH}$ & 108.8 & $76.0-132.0$ & 119.4 & $92.7-150.3$ & 105.9 & $80.0-120.7$ & 100.6 & 8.76 \\
\hline TGW & 44.6 & $33.0-54.7$ & 46.0 & $33.5-58.9$ & 43.7 & $39.4-49.0$ & 44.4 & 3.92 \\
\hline GN & 40.9 & $27.4-57.0$ & 37.6 & $23.8-55.2$ & 49.3 & $30.6-69.5$ & 55.2 & 5.02 \\
\hline GW & 1.84 & $1.07-2.43$ & 1.77 & $0.80-3.00$ & 2.14 & $1.33-2.94$ & 2.50 & 0.30 \\
\hline $\mathrm{PC}$ & 12.2 & $10.3-13.8$ & 13.4 & $10.5-17.9$ & 12.7 & $11.2-15.8$ & 12.4 & 0.83 \\
\hline $\mathrm{SC}$ & 62.0 & $60.7-63.3$ & 61.3 & $57.3-63.5$ & 61.7 & $58.4-63.4$ & 62.0 & 0.73 \\
\hline $\mathrm{GC}$ & 25.9 & $20.5-30.2$ & 28.4 & $22.8-38.4$ & 26.9 & $23.6-33.7$ & 25.7 & 1.88 \\
\hline $\mathrm{ZT}$ & 38.8 & $27.0-48.0$ & 44.3 & $33.5-57.0$ & 45.3 & $37.5-53.0$ & 44.8 & 3.30 \\
\hline TAC & 48.2 & $7.8-93.4$ & 61.0 & $21.6-120.2$ & 12.7 & $2.87-28.8$ & 15.5 & 13.02 \\
\hline ASH & 1.74 & $1.58-1.93$ & 1.57 & $1.43-1.78$ & 1.69 & 1.571 .81 & 1.57 & 0.11 \\
\hline
\end{tabular}

Abbreviations see Table 2

$L S D_{0.05}$ - least significant difference at the level $\alpha=0.05$ 
significantly influenced content and composition of anthocyanin pigments.

Higher precipitations in the period of intensive growth in the vegetation 2013/14 induced higher plant height (by $16.3 \mathrm{~cm}$ ), grain weight and starch content (by $12.2 \%$ and $1.6 \%$, respectively) compared to the previous vegetation.

Quantitative and qualitative traits among and within colour groups (Table 3, 4)

Significant differences were found among colour groups nearly in all evaluated traits (except heading, TGW and starch content). The earliest were varieties with yellow grains (heading - May, 18 to 19, on average), a day later purple ones and approximately 5 days later blue grain wheats. In each wheat group, high variability and varieties earlier compared to Ilona (average heading from May, 3 to 5) were found. The highest plant height had blue varieties $(119.4 \mathrm{~cm})$ and the lowest wheat varieties with yellow endosperm $(105.9 \mathrm{~cm})$. The highest number and weight of grains per spike were in varieties with yellow endosperm (49.3 pcs and $2.14 \mathrm{~g}$, respectively) and the lowest results were determined for blue grain wheats (1.77 g and $37.6 \mathrm{pcs}$ ). Varieties with yellow endosperm showed lower weight and number of grains per ear compared to the control Ilona by $14.4 \%$ and $10.4 \%$, respectively, and were comparable to Zeleny test. A valuable source of high grain weight per ear and TGW is the blue grain variety Scorpion (2.85 g and $57.2 \mathrm{~g}$, respectively). These parameters were declared in the variety description presented by Martinek et al. (2013b). Variety Scorpion is suitable for baking bread, since intake of anthocyanins may play an important role in the prevention of human diseases (Bartl et al. 2015). Compared to control Ilona, the blue wheats showed good qualitative traits in term of protein as well as gluten content.

Our results are in agreement with other research finding and suggest that blue wheat varieties contain higher anthocyanin contents compared to purple seeds (Ficco et al. 2014; Žofajová et al. 2012 and others). The highest total anthocyanin content was observed in K 3575 699/3, what was by 33.5\% higher compared to Scorpion. Purple wheats were rich in ash content, what was significantly higher compared to Ilona.

To compare grain yield traits of colour wheats (mainly purple and blue) to the red control variety Ilona we can confirm that the main objective in coloured wheat breeding is increasing the grain yield. Growing of colour wheats will depend on the grain yield and agronomic characters, comparable to commercial wheat varieties. In this direction, some progress has been achieved as reported Garg et al. (2016), who selected pigmented lines with commercial potential, having grain yield and thousand grain weight equivalent to the high yielding commercial cultivars. Anthocyanin rich lines adapted to local growing conditions were developed from low yielding exotic donor lines.

T a b 1 e 4

Average values of selected traits of coloured winter wheat over two growing seasons (2012/13, 2013/14) at Piešt’any, Slovakia

\begin{tabular}{|l|c|c|c|c|c|c|c|c|c|c|}
\hline Varieties & colour & TGW & GN & GW & PC & SC & GC & ZT & TAC & ASH \\
\hline PS Karkulka & purple & $48.4^{\mathrm{ab}}$ & $39.0^{\mathrm{a}}$ & $1.91^{\mathrm{a}}$ & 12.8 & 61.9 & 26.8 & 42.8 & $44.7^{\mathrm{abc}}$ & $1.83^{\mathrm{c}}$ \\
PS 5711 & purple & $42.1^{\mathrm{a}}$ & $41.1^{\mathrm{ab}}$ & $1.73^{\mathrm{a}}$ & 12.4 & 61.5 & 26.6 & 41.7 & $36.8^{\mathrm{ab}}$ & $1.66^{\mathrm{ab}}$ \\
K 3575 699/3 & blue & $54.4^{\mathrm{b}}$ & $35.2^{\mathrm{a}}$ & $1.92^{\mathrm{a}}$ & 13.0 & 61.8 & 28.1 & 46.6 & $76.1^{\mathrm{c}}$ & $1.61^{\mathrm{ab}}$ \\
Scorpion & blue & $57.2^{\mathrm{b}}$ & $50.2^{\mathrm{bc}}$ & $2.85^{\mathrm{b}}$ & 13.0 & 61.7 & 26.9 & 42.3 & $57.0^{\mathrm{bc}}$ & $1.54^{\mathrm{a}}$ \\
Bona Vita & yellow & $41.8^{\mathrm{a}}$ & $40.6^{\mathrm{a}}$ & $1.70^{\mathrm{a}}$ & 14.2 & 59.9 & 29.7 & 46.0 & $17.9^{\mathrm{a}}$ & $1.70^{\mathrm{bc}}$ \\
Luteus & yellow & $42.8^{\mathrm{a}}$ & $50.6^{\mathrm{c}}$ & $2.16^{\mathrm{a}}$ & 11.7 & 63.0 & 25.0 & 44.5 & $8.6^{\mathrm{a}}$ & $1.67^{\mathrm{ab}}$ \\
\hline Mean & - & 47.8 & 42.8 & 2.05 & 13.0 & 61.7 & 27.2 & 44.0 & 40.2 & 1.67 \\
LSD $_{0.05}$ & - & 8.85 & 9.47 & 0.57 & 1.72 & 1.36 & 3.98 & 6.18 & 38.40 & 0.15 \\
\hline
\end{tabular}

Abbreviations see Table 2

$L S D_{0.05}$ - least significant difference at the level $\alpha=0.05$

Different letters within the same column of each trait indicate significant differences at $P<0.05$ 


\section{Anthocyanin composition}

Anthocyanin composition in selected wheat varieties differing in grain colours was evaluated by HPLC analysis. HPLC analysis is method for detailed description of differences between analysed varieties of wheat because photometric determination of total anthocyanins is not sensitive to differentiation of varietal specificities such as composition of anthocyanins, presence of other coloured compounds and effects of non-coloured compounds interfered during spectrophotometric determination. HPLC fingerprints in Figure 1 show composition of individual anthocyanins and other compounds (serotonin, melatonin and secoisolariciresinol diglucoside). Similar fingerprints have been also presented in wheat varieties by Hosseinian et al. (2007). These fingerprints prove that varieties Ilona (1), Luteus (2) and Bona Vita (3) do not contain anthocyanins whereas varieties Scorpion (4), K 3575 699/3 (5) (blue) and varieties PS 5711 (6) and PS Karkulka (7) (purple) contain some compounds with elution and chromogenic properties characteristic for anthocyanins. The peak areas of all these compounds expressed by percentage of total colour is described in Table 5. From the Table 5 it is evident that the colour of studied varieties is not caused only by presence of anthocyanins. Anthocyanins caused contribution to wheat colour in the range from 0 (Bona Vita) to $96 \%$ (PS 5711) of total colour which can be determined by classic methods based on spectrophotometric analysis (Table 4). The most common anthocyanin in purple wheat is cyanidin-3-O-glucoside, followed by peonidin-3-O-glucoside, whereas delphidin-3-0-glucoside is the most abundant anthocyanin in wheat (Abdel-Aal \& Hucl 2003; Escribano-Bailón et al. 2004). On the base of described chromatographic method and spectral properties of separated compounds, anthocyanins were eluted from chromatographic column in retention time varied from 1.74 to 34.14 minutes. Compounds eluted out of this range can be included into groups of proteins, melatonins and serotonins (Hosseinian et al. 2007).

\section{Grain minerals content (Table 6)}

Concentration of mineral elements including $\mathrm{Fe}$ and $\mathrm{Zn}$ in wheat grains is important for human

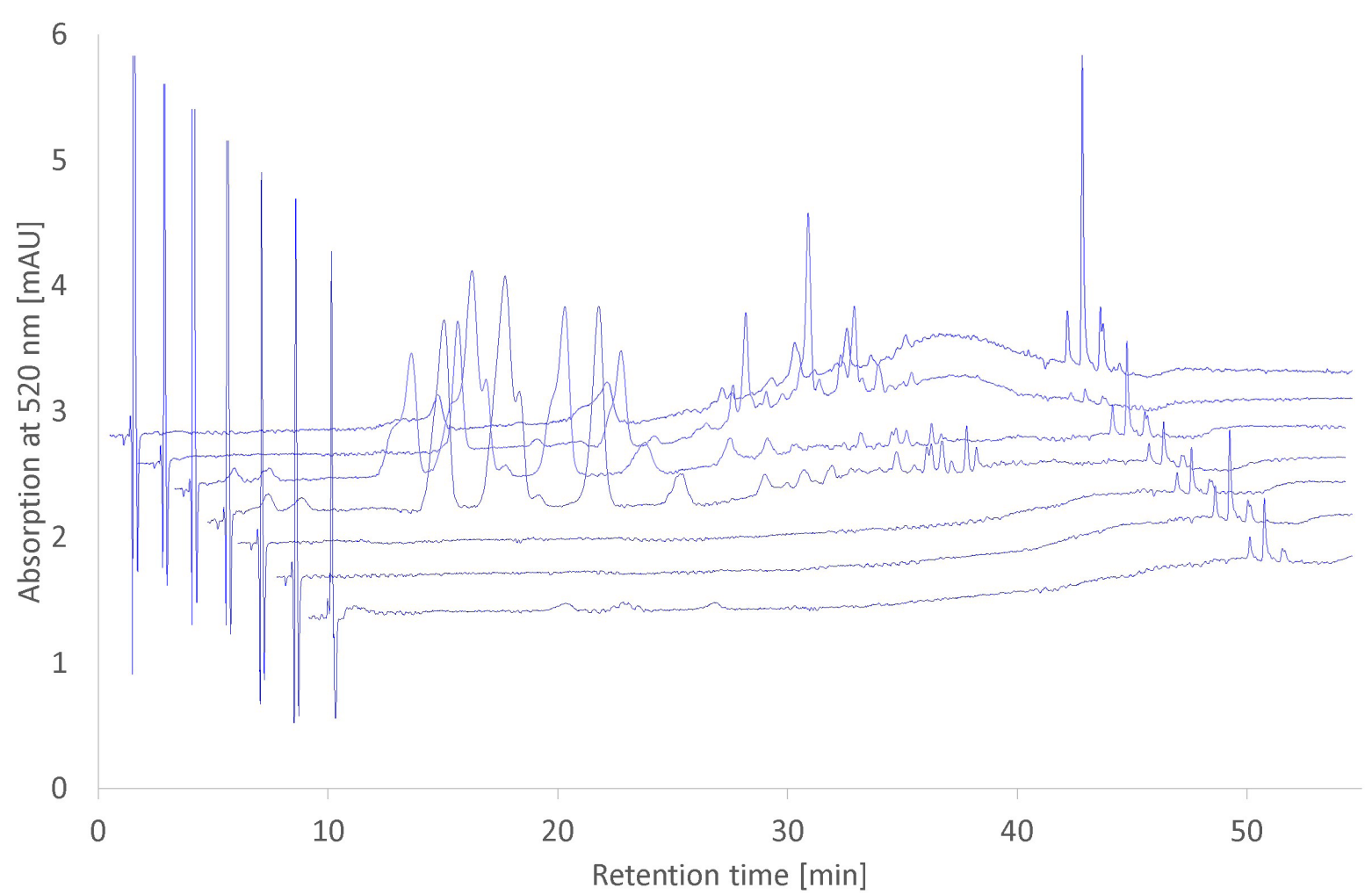

Figure 1. HPLC fingerprints of wheat extract determined at $520 \mathrm{~nm}$; samples are in ascending order (upper is sample 7 and lower is sample 1) (1 - Ilona, 2 - Luteus, 3 - Bona Vita, 4 - Scorpion, 5 - K3575 699/3, 6 - PS 5711, 7 - PS Karkulka) 
health. For deeper characterisation of grain coloured wheats, seven selected varieties were explored for minerals content. There were no significant differences among different colour winter wheat groups in $\mathrm{Fe}, \mathrm{Zn}, \mathrm{Cu}$ and $\mathrm{Mn}$ content (results not shown). The highest $\mathrm{Fe}$ in the grain showed the purple varieties in average $(34.20 \mathrm{mg} / \mathrm{kg})$ and the lowest varieties with yellow endosperm $(32.09 \mathrm{mg} / \mathrm{kg})$, which contrary showed the highest content of $\mathrm{Zn}$ and $\mathrm{Mn}$ (21.42 $\mathrm{mg} / \mathrm{kg}$ and $29.72 \mathrm{mg} / \mathrm{kg}$, respectively). In regard to small number of evaluated varieties and composition of file we could not confirm the results published by Ficco et al. (2014), who by evaluation of 76 colour wheats genotypes showed the highest content of $\mathrm{Zn}$ and $\mathrm{Fe}$ in blue grain wheat and in $\mathrm{Cu}$ and $\mathrm{Mn}$ he did not record any definite trend. On the

T a b 1 e 5

The contribution of anthocyanins to colour of selected wheat varieties

\begin{tabular}{|c|c|c|c|c|c|c|c|c|}
\hline \multirow{2}{*}{$\begin{array}{l}\text { Peak } \\
\text { No. }\end{array}$} & \multirow{2}{*}{$\begin{array}{l}\text { Retention time } \\
\quad[\mathrm{min}]\end{array}$} & \multicolumn{7}{|c|}{ Colourful contribution of anthocyanins [\%] } \\
\hline & & Ilona & Luteus & Bona Vita & Scorpion & $\begin{array}{c}\text { K3575 } \\
699 / 3 \\
\end{array}$ & PS 5711 & $\begin{array}{c}\text { PS } \\
\text { Karkulka }\end{array}$ \\
\hline 1 & 1.735 & 0 & 36.4 & 0 & 4.01 & 0 & 0 & 0 \\
\hline 2 & 2.103 & 0 & 8.21 & 0 & 0 & 0 & 0 & 0 \\
\hline 3 & 2.325 & 36.53 & 0 & 0 & 0 & 0 & 0 & 0 \\
\hline 4 & 3.021 & 9.91 & 0 & 0 & 1.37 & 1.50 & 0 & 0 \\
\hline 5 & 4.534 & 0 & 0 & 0 & 0 & 1.50 & 0 & 0 \\
\hline 6 & 10.976 & 0 & 0 & 0 & 16.63 & 12.73 & 0 & 0 \\
\hline 7 & 13.690 & 0 & 0 & 0 & 19.57 & 20.82 & 0 & 0 \\
\hline 8 & 14.351 & 4.22 & 0 & 0 & 9.58 & 0 & 0 & 0 \\
\hline 9 & 14.651 & 2.87 & 0 & 0 & 0 & 9.94 & 14.73 & 6.61 \\
\hline 10 & 14.900 & 0 & 0 & 0 & 0.65 & 0 & 0 & 0 \\
\hline 11 & 17.775 & 0 & 0 & 0 & 17.61 & 1.15 & 0 & 0 \\
\hline 12 & 20.992 & 0 & 0 & 0 & 2.74 & 17.35 & 8.59 & 0 \\
\hline 13 & 21.413 & 0 & 0 & 0 & 0 & 0 & 0 & 0 \\
\hline 14 & 23.000 & 0 & 0 & 0 & 0 & 3.35 & 10.55 & 0 \\
\hline 15 & 24.670 & 0 & 0 & 0 & 1.46 & 0 & 0.95 & 0 \\
\hline 16 & 25.303 & 0 & 0 & 0 & 0 & 0 & 0 & 0 \\
\hline 17 & 26.623 & 0 & 0 & 0 & 1.37 & 2.42 & 0.94 & 0 \\
\hline 18 & 27.068 & 0 & 0 & 0 & 0 & 1.96 & 3.92 & 0 \\
\hline 19 & 27.974 & 0 & 0 & 0 & 1.37 & 0 & 11.17 & 0 \\
\hline 20 & 28.692 & 0 & 0 & 0 & 1.37 & 0.77 & 1.59 & 0 \\
\hline 21 & 29.775 & 0 & 0 & 0 & 0 & 0 & 0.88 & 0 \\
\hline 22 & 29.851 & 0 & 0 & 0 & 0 & 0.76 & 0 & 0 \\
\hline 23 & 30.675 & 0 & 0 & 0 & 1.86 & 0 & 20.86 & 0 \\
\hline 24 & 31.286 & 0 & 0 & 0 & 0.73 & 1.73 & 1.84 & 0 \\
\hline 25 & 31.888 & 0 & 0 & 0 & 2.15 & 0 & 4.29 & 0 \\
\hline 26 & 32.242 & 0 & 0 & 0 & 2.35 & 1.50 & 9.57 & 0 \\
\hline 27 & 32.625 & 0 & 0 & 0 & 2.73 & 0 & 0 & 0 \\
\hline 28 & 32.831 & 0 & 0 & 0 & 1.07 & 1.62 & 1.59 & 0 \\
\hline 29 & 33.723 & 0 & 0 & 0 & 4.01 & 2.19 & 3.06 & 0 \\
\hline 30 & 34.141 & 0 & 0 & 0 & 1.95 & 0 & 0 & 0 \\
\hline
\end{tabular}


T $\quad$ a

Grain minerals concentration of coloured winter wheat genotypes evaluated during the 2013/14 growing season at Piešt'any, Slovakia

\begin{tabular}{|l|c|c|c|c|c|}
\hline Varieties & Colour & Fe $[\mathrm{mg} / \mathrm{kg}]$ & $\mathrm{Zn}[\mathrm{mg} / \mathrm{kg}]$ & $\mathrm{Cu}[\mathrm{mg} / \mathrm{kg}]$ & $\mathrm{Mn}[\mathrm{mg} / \mathrm{kg}]$ \\
\hline PS Karkulka & purple & $37.71^{\mathrm{b}}$ & $22.84^{\mathrm{d}}$ & 5.04 & $31.23^{\mathrm{d}}$ \\
PS 5711 & purple & $30.71^{\mathrm{a}}$ & $18.80^{\mathrm{a}}$ & 3.92 & $22.33^{\mathrm{a}}$ \\
K 3575 699/3 & blue & $32.83^{\mathrm{a}}$ & $19.53^{\mathrm{ab}}$ & 4.08 & $26.01^{\mathrm{b}}$ \\
Scorpion & blue & $33.52^{\mathrm{a}}$ & $20.25^{\mathrm{abc}}$ & 4.19 & $30.25^{\mathrm{cd}}$ \\
Bona Vita & yellow & $32.13^{\mathrm{a}}$ & $21.82^{\mathrm{cd}}$ & 4.68 & $30.47^{\mathrm{cd}}$ \\
Luteus & yellow & $31.93^{\mathrm{a}}$ & $21.03^{\mathrm{bcd}}$ & 4.27 & $28.98^{\mathrm{c}}$ \\
Ilona & control (red) & $30.85^{\mathrm{a}}$ & $21.17^{\mathrm{bcd}}$ & 4.70 & $28.87^{\mathrm{c}}$ \\
\hline Mean & - & 32.81 & 20.78 & 4.41 & 28.31 \\
$L S D_{0.05}$ & - & 2.84 & 2.06 & 1.09 & 1.82 \\
\hline
\end{tabular}

$L S D_{0.05}$ - least significant difference at the level $\alpha=0.05$

Different letters within the same column of each trait indicate significant differences at $P<0.05$

contrary, Guo et al. (2013) analysed nutrient composition in seven purple lines and found out $100 \%$ higher Fe content compared to control, white grain wheat.

Varieties with purple grain possessed the highest variability in all mineral elements. The registered variety PS Karkulka showed the highest mineral content and the lowest was observed in PS 5711. In grain mineral content instead of $\mathrm{Mn}$, the newly bred blue genotype K 3575 699/3 was comparable with registered blue variety Scorpion. Among varieties, there were significant differences in $\mathrm{Fe}, \mathrm{Zn}$ and $\mathrm{Mn}$ contents. The highest coefficient of variability $(12.43 \%)$ was in $\mathrm{Cu}$ content and differences among varieties were not significant. The lowest coefficient of variability $(1.90 \%)$ was in Mn content. Control variety Ilona was comparable in $\mathrm{Zn}$ and $\mathrm{Mn}$ content to the average value for coloured wheats and its grains showed more $\mathrm{Cu}$ (by 7.8\%) and less $\mathrm{Fe}$ (by $6.9 \%$ ). Variability in the content of mineral elements can be used in breeding for improved mineral availability in the end products. Information about the mineral content in the evaluated genotypes are within the range that published Ficco et al. (2014) and Zhang et al. (2010).

In Slovakia, there is an interest in coloured wheat observed especially in the production of extruded cereal products (puffed bread). Our assumption is to utilize coloured wheat grains in the production of baker's ware (Rückschloss et al. 2011). Martinek et al. (2013a) noticed that it will be necessary to know the extent of natural degradation of dyes during thermal processing of the wheat grain when during Maillard reaction chemical changes occur. The coating grain layers would be used for fortification of dairy products (for example yogurt), where not only the beneficial component of pigments, but also high content of dietary fibre will be used (Rückschloss et al. 2011).

\section{CONCLUSIONS}

Anthocyanin content in 17 colour wheat was influenced by weather conditions of experimental years and their interaction. The higher temperature and unequal distribution of precipitation caused reduction in anthocyanin content. Blue varieties contained higher anthocyanin content compared to purple ones. The highest total anthocyanin content showed K 3575 699/3 (blue grain newly bred), what was by $33.5 \%$ higher compared to blue registered variety Scorpion. K 3575 699/3 can be utilised in breeding programmes as a source of high anthocyanin content. Blue varieties (in average) were the highest in plant height and the lowest in number and weight of grain per spike, which may be negative for their commercial cultivation. However, the highest grain weight per ear and TGW were confirmed in the variety Scorpion. The registered purple variety 
PS Karkulka showed the highest mineral content (Fe, $\mathrm{Zn}, \mathrm{Cu}, \mathrm{Mn}$ ). Purple bred PS 5711 not reached the variety PS Karkulka in quantitative or qualitative traits. Varieties with yellow endosperm were the most yielding, but worse compared to the control Ilona.

Acknowledgements. This work was supported by the Operational Programme Research and Development for the project: "Implementation of the research of plant genetic resources and its maintaining in the sustainable management of Slovak republic" (ITMS: 26220220097), co-financed through the resources of the European Union Fund for Regional Development and by the project SRDA-0758-11. The authors are grateful to Ing. Rückschloss and Ing. Hanková, $\mathrm{PhD}$. for supplying wheat seeds and valuable advice.

\section{REFERENCES}

ABDEL-AAL, E.S.M. - HUCL, P. 2003. Composition and stability of anthocyanins in blue-grained wheat. In Journal of Agricultural and Food Chemistry, vol. 51, pp. 2174-2180.

ABDEL-AAL, ESM - HUCL, P. - SHIPP, J. - RABALSKI, I. 2016. Compositional differences in anthocyanins from blue- and purple-grained spring wheat grown in four environments in Central Saskatchewan. In Cereal Chemistry, vol. 93, no. 1, pp. 32-38.

BARTL, P. - ALBREHT, A. - SKRT, M. - TREMLOVÁ, B. OŠÁDALOVÁ, M. - ŠMEJKAL, K. - VOVK, I. - ULRIH, N.P. 2015. Anthocyanins in purple and blue wheat grains and in resulting bread: Quantity, composition, and thermal stability. In International Journal of Food Sciences and Nutrition, vol. 66, no. 5, pp. 514-519.

ESCRIBANO-BAILÓN, M.T. - SANTOS-BUELGA, C. RIVAS-GONZALO, J. 2004. Anthocyanins in cereals. In Journal of Chromatography A, vol. 1054, pp. 129-141.

ESPOSITO, D. - CHEN, A. - GRACE, M.H. KOMARNYTSKY, S. - LILA, M.A. 2014. Inhibitory effects of wild blueberry anthocyanins and other flavonoids on biomarkers of acute and chronic inflammation in vitro. In Journal of Agricultural and Food Chemistry, vol. 62, pp. 7022-7028.

ESPOSITO, D. - DAMSUD, T. - WILSON, M. - CHEN, A. - STRAUCH, R. - LI, X. - KOMARNYTSKY, S. 2015. Black currant anthocyanins attenuate weight gain and improve glucose metabolism in diet-induced obese mice with intact, but not disrupted, gut microbiome. In Journal of Agricultural and Food Chemistry, vol. 63, pp. 6172-6180.

FERNANDES, I. - FARIA, A. - CALHAU, C. - De FREITAS, V. - MATEUS, N. 2014. Bioavailability of anthocyanins and derivatives. In Journal of Functional Foods, vol. 7, pp. $54-66$.

FICCO, D.B.M. - De SIMONE, V. - COLECCHIA, S.A. - PECORELlA, I. - PLATANI, C. - NIGRO, F. FINOCCHIARO, F. - PAPA, R. - De VITA, P. 2014. Genetic variability in anthocyanin composition and nutritional properties of blue, purple and red bread (Triticum aestivum L.) and durum (Triticum turgidum L. ssp. turgidum convar. durum) wheats. In Journal of Agricultural and Food Chemistry, vol. 62, pp. 8686-8695. DOI: 10.1021/ jf5003683

FICCO, D.B.M. - De SIMONE, V. - De LEONARDIS, A.M. GIOVANNIELLO, V. - Del NOBILE, M.A. - PADALINO, L. - LECCE, L. - BORRELLI, G.M. - De VITA, P. 2016. Use of purple durum wheat to produce naturally functional fresh and dry pasta. In Food Chemistry, vol. 205, pp. 187-195. DOI: 10.1016/j.foodchem.2016.03.014

GARG, M. - CHAWLA, M. - CHUNDURI, V. - KUMAR, R. - SHARMA, S. - SHARMA, N.K. - NAVNEET KAUR, N. - KUMAR, A. - MUNDEY, J.K. - SAINI, M.K. - SINGH, S.P. 2016. Transfer of grain colors to elite wheat cultivars and their characterization. In Journal of Cereal Science, vol. 71, pp. 138-144.

GUO, Z.F. - ZHANG, Z.B. - XU. P. - GUO, Y.N. 2013. Analysis of nutrient composition of purple wheat. In Cereal Research Communications, vol. 41, no. 2, pp. 293-303. DOI: 10.1556/CRC.2012.0037

HANKOVÁ, A. - MATÚŠKOVÁ, K. - RÜCKSCHLOSS, L. - ŽOFAJOVÁ, A. 2014. Winter wheat PS Karkulka. In Agriculture (Polnohospodárstvo), vol. 60, no. 4, pp. 159-161.

HOSSEINIAN, F. - LI, W. - BETA, T. 2007. Measurement of anthocyanins and other phytochemicals in purple wheat. In Food Chemistry, vol. 109, pp. 916-924.

JAAFAR, S.N.S. - BARON, J. - SIEBENHANDL-EHN, S. ROSENAU, T. - BÖHMDORFER, S. - GRAUSGRUBER, H. 2013. Increased anthocyanin content in purple pericarp $\times$ blue aleurone wheat crosses. In Plant Breeding, vol. 132, no. 6, pp. 546-552. DOI: 10.1111/pbr.12090

JOHNSON, M.H. - WALLIG, M. - LUNA VITAL, D.A. De EJIA, E.G. 2016. Alcohol-free fermented blueberryblackberry beverage phenolic extracts attenuates dietinduced obesity and blood glucose in C57BL/6J mice. In The Journal of Nutritional Biochemistry, vol. 31, pp. 45-59.

LACHMAN, J. - MARTINEK, P. - KOTÍKOVÁ, Z. - ORSÁK, M. - ŠULC, M. 2017. Genetics and chemistry of pigments in wheat grain - A review. In Journal of Cereal Science, vol. 74, pp. 145-154.

LI, Q. - SOMAVAT, P. - SINGH, V. - CHATHAN, L. - De MEJIA, E.G. 2017. A comparative study of anthocyanin distribution in purple and blue corn coproducts from three conventional fractionation processes. In Food Chemistry, vol. 231, pp. 332-339.

LI, Y. - MA, D. - SUN, D.X. - WANG, C. - ZHANG, J. - XIE, Y. - GUO, T. 2015. Total phenolic, flavonoid content, and antioxidant activity of flour, noodles, and steamed bread made from different colored wheat grains by three milling methods. In The Crop Journal, vol. 3, no. 4, pp. 328-334.

MARTINEK, P. - JIRSA, O. - VACULOVÁ, K. - CHRPOVÁ, J. - WATANABE, N. - BUREŠOVÁ, V. - KOPECKÝ, D. - ŠTIASNA, K. - VYHNÁNEK, T. - TROJAN, V. $2013 \mathrm{a}$. Use of wheat gene resources with different grain colour in breeding 64. Tagung der vereinigung der Pflanzenzüchter und Saatgutkaufleute Österreichs, 25.-26. November 2013, Raumberg-Gumpenstein, pp. 75-78.

MARTINEK, P. - ŠKORPÍK, M. - CHRPOVÁ, J. - FUČÍK, P. - SCHWEIGER, J. 2013b. Development of the new winter wheat variety Skorpion with blue grain. In Czech Journal of Genetics and Plant Breeding, vol. 49, pp. 90-94.

REQUE, P.M. - STEFFENS, R.S. - JABLONSKI, A. FLÔRES, S.H. - RIOS, A.D.O. - De JONG, E.V. 2014. Cold storage of blueberry (Vaccinium spp.) fruits and juice: Anthocyanin stability and antioxidant activity. In Journal 
of Food Composition and Analysis, vol. 33, pp. 111-116. RÜCKSCHLOSS, L. - HANKOVÁ, A. - VALČUHOVÁ, D. 2011. Quo vadis šlachtenie pšenice? Web: http://old. agroporadenstvo.sk/rv/obilniny/psenica_slachtenie.htm

STN ISO 2171, 2008. Obilniny, strukoviny a výrobky z nich. Stanovenie celkového popola spal'ovaním [Cereals, pulses and by-products. Determination of ash yield by incineration]. Bratislava : Slovenský ústav technickej normalizácie, Bratislava, $16 \mathrm{p}$.

VARGA, M. - BÁNHIDY, J. - CSEUZ, L. - MATUZ, J. 2013.

The anthocyanin content of blue and purple coloured wheat cultivars and their hybrid generations. In Cereal Research Communications, vol. 41 , no. 2, pp. 284-292. DOI: 10.1556/CRC.2013.2.10
ZHANG, Y. - SONG, Q. - YAN, J. - TANG, J. - ZHAO, R. - ZHANG, Y. - HE, Z. - ZOU, CH. - ORTIZMONASTERIO, I. 2010. Mineral element concentrations in grains of Chinese wheat cultivars. In Euphytica, vol. 174, pp. 303-313. DOI 10.1007/s10681-009-0082-6

ŽOFAJOVÁ, A. - PŠENÁKOVÁ, I. - HAVRLENTOVÁ, M. PILIAROVÁ, M. 2012. Accumulation of total anthocyanins in wheat grain. In Agriculture (Pol'nohospodárstvo), vol. 58, no. 2 , pp. 50-56. DOI: 10.2478/v10207-012-0006-7

Received: June 28, 2017 